\title{
Role of Galphaq Containing Protein in Immune Regulation
}

\author{
Yuan Liu, Lu Gan and Guixiu Shi \\ Division of Rheumatology and Clinical Immunology, \\ State Key Laboratory of Biotherapy, West China Hospital, Sichuan University, China
}

Received 2012-09-03, Revised 2012-09-07; Accepted 2012-10-18

\begin{abstract}
$\mathrm{G}$ proteins, one of the most important transmembrane signal transducers, contain four subfamilies. $\mathrm{G}_{\alpha \mathrm{q}}$ is the $\alpha$ subunit of $G_{q}$ protein subfamily. The $G_{\alpha q}$ containing protein initially attracted attention for its physiological significance is in cardiovascular system. In recent years, its role in immune regulation has been indicated. Studies domenstrated that $\mathrm{G}_{\alpha \mathrm{qq}}$ plays crucial role in regulating both innate and adaptive immune cells function and it is involved in the development of autoimmune disease. In this review, we summarized recent data in the role of $\mathrm{G}_{\alpha q}$ containing protein in regulating immune cells function and the possible mechanisms.
\end{abstract}

Keywords: $\mathrm{G}_{\alpha \mathrm{q}}$, Heterotrimeric $\mathrm{G}$ Proteins, Immune Cells, Autoimmune Disease

\section{INTRODUCTION}

$\mathrm{G}_{\alpha \mathrm{q}}$, the $\alpha$ subunit of $\mathrm{G}_{\mathrm{q}}$ protein, is ubiquitously expressed in mammalian cells and couples a huge variety of receptors to channel proteins, enzymes and other effector molecules (Wettschureck and Offermanns, 2005; Mizuno and Itoh, 2009). The heterotrimeric Gproteins, are one of the most important transmembrane signal transducers. There are a large number of heterotrimeric guanine nucleotide-binding proteins which interact with the cytoplasmic domains of membrane embedded receptors (G Protein-Coupled Receptors, GPCR). They transduce extracellular signals that affect many biological actions. G-proteins consist of an $\alpha$-subunit that binds and hydrolyses GTP as well as a $\beta$ - and a $\gamma$-subunit that form an undissociable complex. Based on the types of their $\alpha$ subunits, $G$ proteins can be grouped into four subfamilies, they are $G_{\alpha i}, G_{\alpha s}, G_{\alpha q / 11}$ and $G_{12 / 13}$, each subfamily contents several member of $G$ proteins. The $G_{\alpha q / 11}$ subfamily consists of four members designated $G_{\alpha q}, G_{\alpha 11}, G_{\alpha 14}, G \alpha_{15 / 16}$, these G-proteins couple a large number of GPCRs for activation of PLC$\beta$ (Oldham and Hamm, 2008).

The $\mathrm{G}_{\alpha \mathrm{q}}$ containing protein initially attracted attention for its physiological significance in cardiovascular system in 1990s (D'Angelo et al., 1997; Adams et al., 1998). In recent years, studies have indicated the important roles of $\mathrm{G}_{\mathrm{q}}$ in regulating both innate and adaptive immunity, which supply us a new insight into the mechanism of immune regulation and autoimmune disease. This review aims to provide a brief review on the role of $\mathrm{G}_{\alpha \mathrm{q}}$ containing protein in regulating immune cell function and the possible mechanisms involved in the regulation.

\subsection{Basic Principles of Mammalian $G_{a q}$ Protein}

The $G_{\alpha q / 11}$ family members were first identified by affinity purification (Pang and Sternweis, 1990) and molecular cloning strategies (Pang and Sternweis, 1989; Strathmann and Simon, 1991). The $\mathrm{G}_{\alpha \mathrm{q}}$ protein is the product of Gnaq gene and composed of a GTPase domain and an $\alpha$-helical domain. The GTPase domain of $\mathrm{G}_{\alpha \mathrm{q}}$ participates in the hydrolysis of GTP to GDP. The domain has three flexible loops, named switch regions I, II and III, whose conformations are dependent upon GDP or GTP binding. The helical domain contains six helices and is unique to $G$ protein $\alpha$ subunit, but the function of helical domain in $G$ protein signaling remains to be fully clarified (Oldham and Hamm, 2008).

The $G_{\alpha q}$ couples receptors to activate PLC- $\beta$ ( $\beta$ isoforms of phospholipase C) (Rhee, 2001). To dynamically couple activated receptors to effectors, it shares the same activation-inactivation cycle with all of the four families of the heterotrimeric $G$ proteins. In the basal state, the GDP-bound $\alpha$-subunit is associated with the $\beta \gamma$-complex. When the $G$ protein-coupled receptors bind to its appropriate ligands (physiological ligands of $\mathrm{G}_{\alpha \mathrm{q}}$ protein-coupled receptors are summarized in

\section{Corresponding Author: Yuan Liu, Division of Rheumatology and Clinical Immunology, State Key Laboratory of Biotherapy,} West China Hospital, Sichuan University, China 
Table 1), the activated receptor couples to the heterotrimeric $G$ protein and promotes the exchange of GDP to GTP on the $\alpha$-subunit. Then the GTP-bound $\alpha$ subunit dissociates from the other subunits and becomes an activated $\alpha$-subunit and a $\beta \gamma$-complex, which transduces signals individually. Signaling is terminated upon the hydrolysis of GTP mediated by the GTPase activity, which is inherent to the $\mathrm{G}$ protein $\alpha$-subunit. The resulting GDP-bound $\alpha$-subunit reassociates with the $\beta \gamma$-complex to enter a new cycle if activated receptors are present (Wettschureck and Offermanns, 2005).

\section{2. $G_{a q}$ in Regulating Innate Immune Cell Function}

The innate immune system is a universal and ancient form of host defense against infection. It provides the first line of host defense and controls the initiation and determination of the effector classes of the adaptive immune response. Cells involved in innate immune system include macrophages/monocytes, dendritic cell, granulocytes and natural killer cells.

The best known about $\mathrm{G}$ proteins in the innate immune system is its role in the chemokine receptor signaling pathway. Directed cell movement in response to an increased concentration of chemokines underlies the correct targeting of leukocytes to lymphatic organs during antigen surveillance and also allows them to migrate to sites of infection or inflammation (Vicente-Manzanares and Sanchez-Madrid, 2004). Many of the key intracellular proteins and second messengers that control cell migrations have been identified and a consensus chemokine receptor signal transduction model has been proposed. One of the critical components of this chemokine receptor signaling model is the heterotrimeric $\mathrm{G}$ protein complex. It directly associates with chemokine receptors and transduces signals from these receptors to other key intracellular signaling molecules. Many studies have elucidated the essential role of Gai in the chemokine receptor signaling pathway. Despite the critical importance of $\mathrm{G}_{\alpha \mathrm{i}}$ in chemokine induced cell trafficking, it has been known for many years that chemokine receptors can also couple to $\mathrm{G}_{\alpha \mathrm{q}}$ family members (Amatruda et al., 1993; 1995; Arai and Charo, 1996; Wittmann et al., 2002). Arai and Charo (1996) proved that type A and type B Monocyte Chemoattractant Protein-1 (MCP-1) receptors and macrophage inflammatory protein-1alpha/RANTES receptor (C-CR1) coupled to $G_{\alpha q}$ in COS-7 cells and HEK-293 cells via cotransfection experiments. Using selectively Gnaq knockout mice, Borchers and his colleague have shown that $G_{\alpha q}$ subunit was required in allergen-induced recruitment of eosinophils to the lung. However, this effect was not dependent on $G_{\alpha q}$ signaling in eosinophils themselves, because murine eosinophils did not express $G_{\alpha q}$ detected by Western blot or sequencing of RT-PCR products using degenerate primers for Gnaq transcripts.
The unique loss of GM-CSF production in the lung of Gnaq-/- mice was responsible for the recruitment of eosinophils. However, the potential effects of the Gnaq deficiency in the target cell have not been resolved, $\mathrm{T}$ cells and/or alveolar macrophages might be involved (Borchers et al., 2002). In one of our previous study, we have proved that $G_{\alpha q}$ is as important as $G_{\alpha i}$ in some chemokine receptors signaling, such as mFPR1 and CCR1. In those chemokine receptor activation induced neutrophil and DC migration, although $\mathrm{G}_{\mathrm{\alpha i} 2}$ was necessary, but it was not sufficient to induce chemotaxis of primary leukocytes to a large array of chemoattractants and alternative $G_{\alpha q}$-coupled pathway must be engaged in the migration of primary neutrophils and DCs (Shi et al., 2007). $G_{\alpha q}$ and CD38 coordinately sustained the calcium response by activating calcium entry. This novel alternative chemokine receptor signaling pathway appeared to be critically important for the initiation of inflammatory responses, as $G_{\alpha q}$ was required for the migration of DCs from the skin to draining lymph nodes after fluorescein isothiocyanate sensitization and the emigration of monocytes from the bone marrow into inflamed skin after contact sensitization (Shi et al., 2007). Chemokine receptors dependent on $\mathrm{G}_{\alpha q}$ are summarized in Table 2 .

\section{3. $G_{a q}$ in Regulating the Function of $T$ and $B$ Cells}

The adaptive immune response is a specific immune response. Adaptive immune responses depend on lymphocytes including $\mathrm{T}$ lymphocytes and $\mathrm{B}$ lymphocytes. To participate in an adaptive immune response, $\mathrm{T}$ cells need to proliferate and differentiate into active $\mathrm{CD} 4^{+}$helper $\mathrm{T}$ cells $(\mathrm{Th})$ and $\mathrm{CD} 8^{+}$cytotoxic cells from their naïve states after encountering antigen.

\section{4. $G_{a q}$ and B Cell}

Studies on the regulation of $G_{\alpha q}$ in $B$ cell are quite few. Bence and his colleagues showed that $G_{\alpha q}$ involved in the activation of Bruton's tyrosine kinase, a protein that is required for normal B-cell development and activation (Bence et al., 1997), suggesting that $\mathrm{G}_{\alpha \mathrm{q}}$ may be involved in $\mathrm{B}$ cell development and activation regulation. Our previous study directly demonstrated that $\mathrm{G}_{\alpha q}$-containing $\mathrm{G}$ protein regulates $\mathrm{B}$ cell selection and survival and it was required to prevent $\mathrm{B}$ celldependent autoimmunity (Misra et al., 2010). $\mathrm{G}_{\alpha q}$ was not required for $\mathrm{B}$ cell development in the bone marrow, However, $\mathrm{G}_{\alpha \mathrm{q}}$ did modulate the development of peripheral $B$ cell. $G_{\alpha q}$ appeared to control the numbers of transitional T1 B cells (T1 cell), T1-derived Marginal Zone B cell (MZB) precursors, as well as mature MZB and Follicular B cells (FOB). The proliferation between WT B cell and Gnaq-/- B cells showed no difference under the sitimulation of anti-IgM or anti-CD40 Abs. 
Table 1. Physiological ligands of $\mathrm{G}_{\alpha q}$ protein-coupled receptors

\begin{tabular}{|c|c|c|c|}
\hline $\begin{array}{l}\text { Endogenous } \\
\text { Ligand }\end{array}$ & Receptor & $\begin{array}{l}\text { Coupling to } \mathrm{G} \\
\text { protein subclass }\end{array}$ & References \\
\hline Glutamate & mGluR1, 5 & $\mathrm{G}_{\alpha \mathrm{g}}$ & (Conn and Pin, 1997) \\
\hline$\alpha$-Ketoglutarate & GPR99 & $\mathrm{G}_{\mathrm{q} / 11}^{\mathrm{q}}$ & (He et al., 2004) \\
\hline Succinate & GPR91 & $\mathrm{G}_{\mathrm{q} / 11}^{\mathrm{TH}}$ & (He et al., 2004) \\
\hline L-Arginine, L-lysine & GPRC6A & $\mathrm{G}_{\mathrm{q} / 11} ?$ & (Wellendorph et al., 2005) \\
\hline Acetylcholine & $\mathrm{M} 1, \mathrm{M} 3, \mathrm{M} 5$ & $\mathrm{G}_{\alpha \mathrm{q}}$ & (Wess, 2004) \\
\hline Epinephrine, norepinephrine & $\alpha 1 \mathrm{~A}, \alpha 1 \mathrm{~B}, \alpha 1 \mathrm{D}$ & $\mathrm{G}_{\mathrm{q} / 11}$ & (Wu et al., 1992) \\
\hline Histamine & H1 & $\mathrm{G}_{\mathrm{q} / 11}^{\mathrm{TH}}$ & (Bakker et al., 2001) \\
\hline Serotonin & 5-HT2A/B/C & $\mathrm{G}_{\alpha \mathrm{q}}$ & (Tanis et al., 2008) \\
\hline $\mathrm{Ca} 2+$ & CaSR & $\mathrm{G}_{\mathrm{q} / 11}$ & (Goodman, 2004) \\
\hline ADP/ATP & $\mathrm{P} 2 \mathrm{Y} 1$ & $\mathrm{G}_{\mathrm{q} / 11}$ & (Fredholm et al., 1997) \\
\hline ATP & P2Y 11 & $\mathrm{G}_{\mathrm{q} / 11}^{\mathrm{TH}}$ & (Fredholm et al., 1997) \\
\hline UDP & P2Y6 & $\mathrm{G}_{\mathrm{q} / 11}^{\mathrm{q} 11}$ & (Fredholm et al., 1997) \\
\hline UTP/ATP & $\mathrm{P} 2 \mathrm{Y} 2, \mathrm{P} 2 \mathrm{Y} 4$ & $\mathrm{G}_{\mathrm{q} / 11}^{\mathrm{TH}}$ & (Fredholm et al., 1997) \\
\hline Fatty acids & GPR40,GPR41 & $\mathrm{G}_{\alpha \mathrm{q}}$ & (Lee et al., 2008) \\
\hline & GPR43 & $\mathrm{G}_{\mathrm{q} / 11}$ & (Brown et al., 2003) \\
\hline & GPR120 & $\mathrm{G}_{\mathrm{q} / 11}^{\mathrm{TH}}$ & (Hirasawa et al., 2004) \\
\hline LTC4, LTD4 & CysLT1 & $\mathrm{G}_{\alpha q}$ & (Parmentier et al., 2012) \\
\hline Lysophosphatidic acid & $\mathrm{LPA} 1 / 2 / 3$ & $\mathrm{G}_{\alpha \mathrm{q}}$ & (Lynch, 2002) \\
\hline Platelet-activating factor & PAF & $\mathrm{G}_{\alpha q}$ & (Prescott et al., 2000) \\
\hline Prostaglandin F2 $\alpha$ (PGF) & FP & $\mathrm{G}_{\alpha \mathrm{q}}$ & (Liu and Clipstone, 2007) \\
\hline Prostaglandin E2 (PGE2) & EP1,EP3 & $\mathrm{G}_{\mathrm{q} / 11}^{\mathrm{q}}$ & (Hata and Breyer, 2004) \\
\hline Thromboxane A2 (TxA2) & $\mathrm{TP}$ & $\mathrm{G}_{\alpha \mathrm{q}}^{\mathrm{q} 11 \mathrm{~T}}$ & $\begin{array}{l}\text { (Narumiya et al., 1999; } \\
\text { Hata and Breyer, 2004) }\end{array}$ \\
\hline Angiotensin II & AT1 & $\mathrm{G}_{\alpha \mathrm{q}}$ & (Gasparo et al., 2000) \\
\hline Bradykinin & B1, B2 & $\mathrm{G}_{\alpha q}$ & (Leeb-Lundberg et al., 2005) \\
\hline Calcitonin & $\mathrm{CT}$ & $\mathrm{G}_{\mathrm{q} / 11}$ & (Poyner et al., 2002) \\
\hline Calcitonin gene-related peptide (CGRP) & CGRP1 & $\mathrm{G}_{\mathrm{q} / 11}^{\mathrm{p} 11}$ & (Poyner et al., 2002) \\
\hline Cholecyctokinin (CCK-8) & CCK1, CCK2 & $\mathrm{G}_{\mathrm{q} / 11}^{\mathrm{q} 11}$ & (Shulkes and Baldwin, 1997) \\
\hline Endothelin-1, -2, -3 & ETA, ETB & $\mathrm{G}_{\alpha q}$ & (Cramer et al., 2001) \\
\hline Gastrin & CCK2 & $\mathrm{G}_{\alpha \mathrm{q}}$ & (Shulkes and Baldwin, 1997) \\
\hline Gastrin-releasing peptide (GRP), bombesin & BB2 & $\mathrm{G}_{\alpha \mathrm{q}}$ & (Battey and Wada, 1991) \\
\hline Ghrelin & GHS-R & $\mathrm{G}_{\mathrm{q} / 11}$ & (Kojima et al., 1999) \\
\hline Gonadotropin-releasing hormone & GnRH & $\mathrm{G}_{\alpha q}$ & (Millar et al., 2004) \\
\hline Kisspeptins, metastin & GPR54 & $\mathrm{G}_{\alpha q}^{\alpha q}$ & $\begin{array}{l}\text { (Roux et al., 2003; } \\
\text { Seminara et al. 2003) }\end{array}$ \\
\hline Melanin-concentrating hormone & MCHR1 & $\mathrm{G}_{\alpha \mathrm{g}}$ & (Fry et al., 2006) \\
\hline Motilin & GPR38 & $\mathrm{G}_{\alpha \mathrm{q}}$ & (Feighner et al., 1999) \\
\hline Neurokinin-A/-B & NK2, NK3 & $\mathrm{G}_{\alpha \mathrm{q}}$ & (Pennefather et al., 2004) \\
\hline Neuromedin-B & NMB-R & $\mathrm{G}_{\alpha \mathrm{q}}$ & (Shapira et al., 1994) \\
\hline Orexin $\mathrm{A} / \mathrm{B}$ & $\mathrm{OX} 1, \mathrm{OX} 2$ & $\mathrm{G}_{\mathrm{q} / 11}^{\mathrm{q}}$ & (Mieda and Yanagisawa, 2002) \\
\hline Oxytocin & OT & $\mathrm{G}_{\alpha q}$ & (Qian et al., 1998) \\
\hline Parathyroid hormone (related peptide) & PTH/PTHrP & $\mathrm{G}_{\alpha q}$ & (Offermanns et al., 1996) \\
\hline Prokineticin-1,2 & PKR1, PKR2 & $\mathrm{G}_{\mathrm{q} / 11}$ & (Soga et al., 2002) \\
\hline Prolactin-releasing peptide & PrRP (GPR10) & $\mathrm{G}_{\mathrm{q} / 11}$ & (Sun et al., 2005) \\
\hline Substance P (SP) & NK1 & $\mathrm{G}_{\alpha q}$ & (Macdonald et al., 1996) \\
\hline Thyrotropin (TSH) & TSHR & $\mathrm{G}_{\mathrm{q} / 11}^{\mathrm{q}}$ & (Vassart and Pardo, 2004) \\
\hline Thyrotropin-releasing hormone (TRH) & TRHR & $\mathrm{G}_{\alpha q}$ & (Aragay et al., 1992) \\
\hline Urotensin II & UT-II (GPR14) & $\mathrm{G}_{\alpha q}$ & (Russell, 2004) \\
\hline Thrombin & PAR-1, PAR-3, PAR-4 & $\mathrm{G}_{\alpha \mathrm{q}}$ & (Vaidyula and Rao, 2003) \\
\hline Trypsin & Trypsin receptor & $\mathrm{G}_{\mathrm{q} / 11}^{\mathrm{q}}$ & (Shapira et al., 1998) \\
\hline Estrogen & mER & $\mathrm{G}_{\alpha q}^{\mathrm{q} / \mathrm{T}}$ & (Qiu et al., 2003) \\
\hline
\end{tabular}

Table 2.Chemokine receptors coupled to $\mathrm{G}_{\alpha c}$

\begin{tabular}{llll}
\hline Recpetor & Cell type & $\mathrm{G}_{\alpha q}$ dependent & References \\
\hline MCP-1 receptor & COS-7 and HEK-293 cell & $\mathrm{Y}$ & (Arai and Charo, 1996) \\
CCR1 & COS-7 and HEK-293 cell & $\mathrm{Y}$ & (Arai and Charo, 1996) \\
& BM neutrophil(mice) & $\mathrm{Y}$ & (Shi et al., 2007) \\
CCR2 & Immature DC(mice) & $?$ & (Shi et al., 2007) \\
CCR7 & DC(mice) & $\mathrm{Y}$ & (Shi et al., 2007) \\
CXCR4 & DC(mice) & $\mathrm{Y}$ & (Shi et al., 2007) \\
mFPR1 & BM neutrophil(mice) & $\mathrm{Y}$ & (Shi et al., 2007) \\
mFPR2 & BM neutrophil(mice) & $\mathrm{Y}$ & (Shi et al., 2007) \\
\hline
\end{tabular}


However, Gnaq-/- B cells proliferated more strongly in response to LPS than their WT counterparts, suggesting that either a higher proportion of Gnaq-/- B cells were responsive to LPS or that Gnaq-/- B cells were hyperresponsive to TLR4 ligands. The survival rate of Gnaq-/- B cells was far greater than the survival rate of wide type $B$ cells at all stages of transitional and mature B cells. Gnaq-deficient B cells was more resistant to BAFF withdrawal. Furthermore, Gnaq-deficient B cells constitutively expressed higher levels of activated Akt, PLC $\gamma 2$ and ERK, suggesting the increased activation of BCR-mediated signaling in Gnaq-/- B cells. Most importantly, Gnaq-deficient mice rapidly developed an autoreactive $\mathrm{B}$ cell repertoire and systemic autoimmunity. These data showed that $\mathrm{G}_{\alpha q}$-containing $\mathrm{G}$ proteins, working in concert with the $\mathrm{BCR}$ and $\mathrm{BAFFR}$ signaling networks, regulate $\mathrm{B}$ cell development and peripheral tolerance induction (Misra et al., 2010).

\section{5. $G_{a q}$ and T Cell}

Role of $\mathrm{G}_{\alpha \mathrm{q}}$ in lymphocyte migration seems contrary to that in innate immune cells. Data from one of our previous study showed that $G_{\alpha q}$ regulates CCR7 and CXCR4 signaling in DCs but not in T cells. Chemotaxis of Gnaq-/- $\mathrm{T}$ cells to these two chemokines was completely normal (Shi et al., 2007). However, Ngai reported that Gnaq knockdown T cells showed significantly enhanced migration induced by CXCL12 and the signals conveyed by $\mathrm{G}_{\alpha q}$ appear to be mediated through a SHP-1 pathway (Ngai et al., 2009). These data suggest that the role of $G_{\alpha q}$ in chemokine receptor signaling regulation is cell type and chemokine receptor specific.

Members of $\mathrm{G}_{\mathrm{q}} / \mathrm{G}_{11}$ family are repeatedly to be indicated in $\mathrm{T}$ cell activation. Activation of primary $\mathrm{T}$ cells with anti-CD3/anti-CD28 leads to recruitment of $\mathrm{G}_{\alpha \mathrm{q}}$ to lipid rafts indicate that $\mathrm{G}_{\alpha \mathrm{q}}$ may be involved in $\mathrm{T}$ cells activation (Abrahamsen et al., 2004). Another study using Gnaq knockout mice demonstrated a role of $\mathrm{G}_{\alpha \mathrm{q}}$ in proximal TCR signaling at the level of Lck (Ngai et al., 2008). Jurkat TAg T cells with Gnaq knockdown displayed reduced activation of Lck and LAT phosphorylation, but paradoxically showed sustained ERK1/2 phosphorylation and increased NFAT-AP-1-reporter activity implicating $G_{\alpha q}$ in the negative control of downstream signaling and IL-2promoter activity. Primary T cells isolated from Gnaqdeficient mice have a similar TCR signaling response with reduced proximal LAT phosphorylation, sustained ERK1/2 phosphorylation and augmented immune responses, including increased secretion of IL-2, IL-5, IL-12 and TNF- $\alpha$. The effects on NFAT-AP-1-reporter activity were sensitive to the Src family kinase inhibitor PP2 and were reversed by transient expression of constitutively active Lck. Furthermore, expression of constitutively active $\mathrm{G}_{\alpha \mathrm{q}}$ Q209L elevated Lck activity and Zap-70 phosphorylation. These data indicated the role of $G_{\alpha q}$ in the fine-tuning of proximal TCR signals at the level of Lck and a negative regulatory role of $G_{\alpha q}$ in transcriptional activation of cytokine responses (Ngai et al., 2008). These signals conveyed by $G_{\alpha q}$ appear to be mediated through a SHP-1 pathway (Ngai et al., 2009).

\section{6. $G_{a q}$ and Autoimmune Disease}

In 2010, we first demonstrated the role of $\mathrm{G}_{\alpha \mathrm{q}}$ in autoimmune disease in Gnaq-/- chimeric mice by reconstituting lethally irradiated $\mathrm{C} 57 \mathrm{BL} / 6 \mathrm{~J}$ recipient mice with Gnaq-/- bone marrow. Gnaq-/- chimeric mice spontaneously developed autoimmunity with multiorgan involvement and joints swelling (Misra et al., 2010). Furthermore, we found that $\mathrm{G}_{\alpha \mathrm{qq}}$ expressions at mRNA and protein levels in the peripheral blood lymphocytes (PBLs) from patients with rheumatoid arthritis (RA) were significantly decreased in comparison of which in healthy individuals. The expression levels of $G_{\alpha q}$ mRNA in PBLs from patients with RA were correlated with RA Disease Activity (DAS28), anti-cyclic citrullinated protein antibodies, Creactive protein and rheumatoid factor. These data suggest that $G_{\alpha q}$ might be involved in the pathogenesis of RA (Wang et al., 2011).

\subsection{The Molecular Mechanisms of $G_{a q}$ in Regulatint Immune Cell Functions 1.8. $G_{a q q}$ and PI3K/Akt Pathway}

Phosphatidylinositol 3-Kinase (PI3K) mediates many of the cellular actions of receptor tyrosine kinases, including effects on glucose metabolism, cell survival and cytoskeletal rearrangements (Katso et al., 2001). The serine/threonine protein kinase Akt, also termed Protein Kinase B (PKB), an important downstream effector of $\mathrm{PI} 3 \mathrm{~K}$, is involved in regulating a similarly wide array of cellular processes as PI3K (Brazil et al., 2004). The PI3K/Akt pathway has broad and distinct roles in both innate and adaptive immune cells, it is activated by a broad array of different stimuli via specific receptors, including the BCR, TCR, cytokine receptors (e.g., interleukin 2), insulin receptor, insulinlike growth factor I receptor, as well as Toll-Like Receptors (TLRs) (Weichhart and Saemann, 2008). 
Table 3. Role of Mitogen-Activated Protein (MAP) kinase family in immune cells regulation

\begin{tabular}{|c|c|c|c|}
\hline MAPK members & Immune cells & Effect & References \\
\hline \multirow[t]{5}{*}{$\overline{\text { ERK }}$} & Macrophages & $\begin{array}{l}\text { mice with selective ERK activation deficits } \\
\text { exhibited deficient in LPS-induced TNF- } \alpha \text { production, } \\
\text { ERK inhibitor PD98059 had a similar effect }\end{array}$ & (Dumitru et al., 2000) \\
\hline & \multirow[t]{4}{*}{$\mathrm{T}$ cell } & $\begin{array}{l}\text { ERK1-deficient mice exhibited defective } \\
\text { thymocyte maturation }\end{array}$ & (Pages et al., 1999) \\
\hline & & $\begin{array}{l}\text { Regulate T cell activation, deficient ERK activation } \\
\text { exist in clones that are anergized }\end{array}$ & (Li et al., 1996; Kane et al., 2000) \\
\hline & & Regulate Th2 differentiation & \\
\hline & & $\begin{array}{l}\text { Study using dominant H-RAS transgenic mice and } \\
\text { inhibitors against MEKs showed that ERK pathway } \\
\text { is required for Th2 differentiation }\end{array}$ & (Yamashita et al., 1999) \\
\hline \multirow[t]{5}{*}{ JNK } & \multirow[t]{5}{*}{$\mathrm{T}$ cell } & $\begin{array}{l}\text { Required in negative selection } \\
\mathrm{T} \text { cell activation and IL- } 2 \text { expression }\end{array}$ & Rincon et al., 1998a) \\
\hline & & $\begin{array}{l}\text { No effect } \\
\text { IL-2 expression defect in mixed lymphocyte } \\
\text { of Jnk1-/- mice and Jnk2-/- mice, absence of JNK2 } \\
\text { alone can result in resistance to anti-CD3-induced } \\
\text { thymocyte apoptosis and defective mature } \\
\text { T cell proliferation. }\end{array}$ & $\begin{array}{l}\text { (Dong et al., 1998; Yang et al., 1998) } \\
\text { (Sabapathy et al., 1999; } \\
\text { Sabapathy and Kallunki, 2001) }\end{array}$ \\
\hline & & $\begin{array}{l}\text { Regulate apoptosis, JNK1-/- T cells exhibited reduced } \\
\text { activation-induced cell death }\end{array}$ & (Dong et al., 1998) \\
\hline & & JNK1 inhibit Th2 differentiation by using Jnk1-/- mice & (Dong et al., 1998) \\
\hline & & $\begin{array}{l}\text { JNK2 is required for Th1 differentiation } \\
\text { by using Jnk2-/- mice }\end{array}$ & (Yang et al., 1998) \\
\hline \multirow[t]{5}{*}{ p38 } & $\begin{array}{l}\text { Macrophages } \\
\text { Dendritic cells }\end{array}$ & $\begin{array}{l}\text { p38-specific inhibitors reduced LPS-induced IL-12 } \\
\text { and IL-1 production, genetic disruption of MKK3-p38 } \\
\text { pathway resulted in a selective defect in IL-12 production }\end{array}$ & (Lu et al., 1999) \\
\hline & \multirow[t]{4}{*}{$\mathrm{T}$ cell } & $\begin{array}{l}\text { Regulates activation-induced cell death, activation of the } \\
\text { p38MAPkinase pathway in vivo induces apoptosis in } \\
\text { CD8+ T cells, but not in CD4+ T cell }\end{array}$ & (Merritt et al., 2000) \\
\hline & & $\begin{array}{l}\text { Required for Th1 differentiation inhibitors of the p } 38 \\
\text { kinases block IFN- } \gamma \text { production by Th1 cells in a } \\
\text { dose-dependent manner and transgenic mice in which a } \\
\text { dominant negative p38ashowed reduced IFN- } \gamma \text { cytokine }\end{array}$ & (Rincon et al., 1998b) \\
\hline & & $\begin{array}{l}\text { T cells from mice deficient in the } \mathrm{p} 38 \text { upstream kinase } \\
\text { MKK } 3 \text { have a defect in IFN- } \gamma \text { production }\end{array}$ & (Lu et al., 1999) \\
\hline & & Regulates IFN- $\gamma$ production in CD $8+\mathrm{T}$ cells & (Merritt et al., 2000) \\
\hline
\end{tabular}

Studies regarding regulation of PI3K and/or Akt by $\mathrm{G}_{\alpha q}$ coupled receptors are somewhat controversial. Some studies suggest that $\mathrm{G}_{\alpha \mathrm{\alpha q}}$ can activate PI3K/Akt by using ligands of $G_{\alpha q}$ coupled receptors, summarized in Table 1. Graness suggest that receptor of bradykinin might couple to $\mathrm{G}_{\alpha \mathrm{qq}}$ to activate PI3K (Graness et al., 1998). Endothelin-1 was also proved to activate PI3K via $\mathrm{G}_{\alpha q / 11}$ (Imamura et al., 1999). Saward proved another ligand of $\mathrm{G}_{\alpha q}$ coupled receptor, angiotensin II, can activate PI3K in vascular smooth muscle cells (Saward and Zahradka, 1997) and it can also activate Akt in vascular smooth muscle cells (Eguchi et al., 1999; Takahashi et al., 1999). Tang et al. (2002) showed that muscarinic receptor is coupled to $G_{\alpha q}$ to activate Akt in $1321 \mathrm{~N} 1$ astrocytoma cells.

There are also some evidences suggested that activated $G_{\alpha q}$ inhibit rather than activate PI3K/Akt activity. Folli et al. (1997) proved that angiotensin II can inhibit PI3K activity in aortic smooth muscle cells. Jiang et al. (1999) proved that endothelin-1 inhibited insulin-stimulated PI3-kinase activity associated with IRS-2 by $50-60 \%$ and inhibited the association of p85 subunit of PI3-kinase to IRS-2. To clarify the effects of $\mathrm{G}_{\alpha \mathrm{q}}$ on the activity of PI3K/Akt, Ballou et al. (2003) used a constitutively active $\mathrm{G}_{\alpha \mathrm{q}}(\mathrm{Q} 209 \mathrm{~L})$ mutant to study the role of $\mathrm{G}_{\alpha q}$ in Akt activation, they showed that transient expression of $\mathrm{G}_{\alpha \mathrm{q}}(\mathrm{Q} 209 \mathrm{~L})$ in Rat-1 fibroblasts inhibited platelet-derived growth factor- or insulininduced the activation of Akt. Expression of $\mathrm{G}_{\alpha \mathrm{q}}$ (Q209L) also attenuated Akt activation promoted by coexpression of constitutively active PI3K in human embryonic kidney 293 cells. The inhibitory effect of $G_{\alpha q}$ on Akt seemed to be independent on phospholipase $\mathrm{C}$ activation and might represses P110 alpha PI3K activity via an physically interaction (Ballou et al., 2003). 


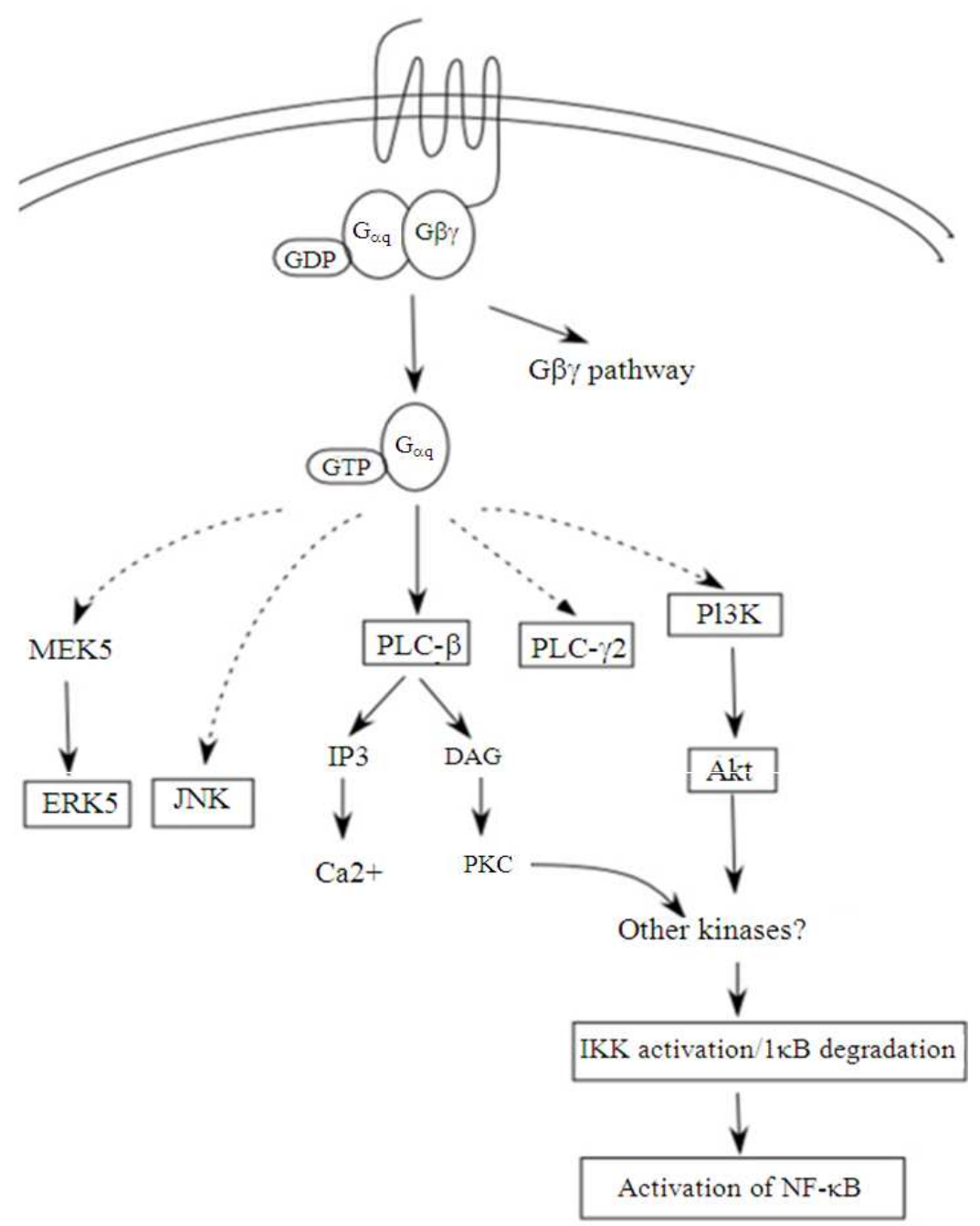

Fig. 1. $G_{\alpha q}$ signaling pathways in immune cells regulation. Activated $G_{\alpha q}$ can directly activate PLC- $\beta$, resulting in generating second messengers IP3 and diacyl glycerol. These molecules promote the activation of conventional PKC (cPKC) and the release of Ca2+ from intracellular stores. Activated $\mathrm{G}_{\alpha \mathrm{q}}$ can regulate the PI3K/Akt activity, this effect seemed to be independent on phospholipase $\mathrm{C}$ activation. $G_{\alpha q}$ was also involved in the transduction of signals from GPCR to ERK. Activated $\mathrm{G}_{\alpha q}$ can lead to NF- $\mathrm{kB}$ activation via PI3K and the PLC- $\beta$ pathway

\section{9. $G_{a q}$ and Mitogen-Activated Protein (MAP) Kinase Family}

The Mitogen-Activated Protein (MAP) kinase signaling cascade is one of the most ancient and evolutionarily conserved signaling pathways which respond to a broad range of extracellular and intracellular changes. The MAPK superfamily includes the Extracellular signalRegulated Kinases (ERK), c-Jun NH2-terminal kinase (JNK1-3) and p38 ( $\alpha, \beta, \gamma$ and $\delta)$ families. In mammalian species, MAP kinases are involved in all aspects of immune responses, from the initiation phase of innate immunity, to activation of adaptive immunity and to cell death when immune function is completed (Dong et al., 2002). The main roles of MitogenActivated Protein (MAP) kinase family in immune cells are summarized in Table 3.

Several studies have indicated the role of $G_{\alpha q}$ in the regulation of Mitogen-Activated Protein (MAP) kinase signaling pathway. Studies on endothelin receptors and gonadotropin-releasing hormone receptors showed that these two types of receptors couple to $\mathrm{G}_{\alpha q}$ to activate ERK 
(Cramer et al., 2001; White et al., 2008). Another study showed that $G_{\alpha q}$ was involved in the transduction of signals from GPCR to ERK5 (Fukuhara et al., 2000; Marinissen et al., 2003). $\mathrm{G}_{a \mathrm{q}}$ displayed a scaffold-like role in this process via independently interacting with both PKC $\delta$ and MEK5 (Garcia-Hoz et al., 2010). It was also reported that $\mathrm{G}_{\alpha \mathrm{q}}$ inhibit TNF alpha-stimulated JNK activation (McIntosh et al., 2010).

\subsection{0. $G_{a q}$ and NF- $\kappa B$}

Nuclear Factor (NF) $\kappa \mathrm{B}$ is one of the most important transcription factors responsible for the expression of these proinflammatory genes. It $\mathrm{s}$ rapid posttranslational activation in response to many pathogenic signals and directly activates the transcription of various genes encoding immunologically relevant proteins. Its properties have been most extensively exploited in cells of the immune system, as reviewed in reference 98 (Baeuerle and Henkel, 1994).

Activated $\mathrm{G}_{\alpha \mathrm{q}}$ can directly activate PLC- $\beta$, resulting in generating second messengers IP3 and diacyl glycerol. These molecules promote the activation of conventional PKC (cPKC) and the release of $\mathrm{Ca}^{2+}$ from intracellular stores. Elevation of intracellular $\mathrm{Ca}^{2+}$ further activates cPKC. Shahrestanifar et al. (1999) have reported that LPA-induced NF- $\mathrm{KB}$ activation can be blocked by the rise of intracellular $\mathrm{Ca}^{2+}$ and $\mathrm{PKC}$ inhibitors. Several PKC isoforms, including cPKC, were known activators of NF- $\mathrm{KB}$ based on early studies on the effects of phorbol esters in NF- $\kappa \mathrm{B}$ activation (Shahrestanifar et al., 1999). Using cell lines with transfected constitutively active mutants of $\mathrm{G}_{\alpha \mathrm{qq}}$, it is demonstrated that a Q209L mutation of $G_{\alpha q}$ lead to activation of NF- $\kappa \mathrm{B}$. Furthermore, based on the inhibitory effects of $\mathrm{IkB} \alpha$ repressor, the $\mathrm{IkB}$ kinases (IKK), including IKK1 (IKK $\alpha)$ and IKK2 (IKK $\beta)$, were involved in the $\mathrm{G}_{\alpha q}$-mediated NF-kB activation. Inhibitors for Phosphatidylinositol (PI) 3-kinase (PI3K), as well as dominant negative constructs of PI3K and its downstream effector Akt (PKB) partially block the $\mathrm{G}_{\alpha q^{-}}$ mediated NF- $\kappa \mathrm{B}$ activation (Xie et al., 2000). These results suggest that $G_{\alpha q}$ activates NF- $\kappa B$ via PI3K and the PLC- $\beta$ pathway. The signaling pathway of $G_{\alpha q}$ in immune cells regulation was shown in Fig. 1.

\section{CONCLUSION}

\subsection{Conclusion and Future Perspectives}

$\mathrm{G}_{\mathrm{aq}}$ is one of the most important proteins in transducing extracellular signals. Their functions in immune responses are beginning to be revealed with help of $\mathrm{G}_{\alpha q}$-specific inhibitors and mouse genetic manipulation. $G_{\alpha q}$ plays crucial role in both innate immune cells and adaptive immune cells function regulation: $1 . \mathrm{G}_{\alpha \mathrm{q}}$ regulates the migration of neutrophils and DCs induced by a large array of chemokines, it also regulates the allergen-induced recruitment of eosinophils; 2. $\mathrm{G}_{\alpha \mathrm{q}}$ regulates $\mathrm{B}$ cell selection and survival and is required to prevent $\mathrm{B}$ cell-dependent autoimmunity; $3 . \mathrm{G}_{\alpha \mathrm{q}}$ regulates migration of $\mathrm{T}$ cell induced by some kinds of chemokines (at least by CXCL12) and it is involved in TCR signaling pathway to regulate $\mathrm{T}$ cells activation and some effector function; 4. $\mathrm{G}_{\alpha \mathrm{q}}$ regulates the development of autoimmune disease, such as RA and the expression levels of $G_{\alpha q}$ mRNA in PBLs from patients with RA were correlated with RA disease activity.

From what we summarized above, we can predict some future directions in the studies of $\mathrm{G}_{\alpha q}$ :

- Exploring the broader function of $\mathrm{G}_{\alpha q}$ in different cell types of the immune system. For instance, the role of $\mathrm{G}_{\alpha \mathrm{q}}$ in macrophages, Breg, Treg or Th17

- Defining the specific downstream targets of $G_{\alpha q}$ in a given stage and cell type of an immune response. There are multiple substrates of $G_{\alpha q}$, which one mediates is function in a given cell type needs to be carefully characterized

- To clarify the role of $\mathrm{G}_{\alpha \mathrm{q}}$ in other types of autoimmune disease, such as Systemic lupus erythematosus; Sjogren's syndrome and dermotomyositis. Understanding the signaling mechanisms of $\mathrm{G}_{\alpha \mathrm{q}}$ in these autoimmune diseases pathogenesis

These results will no doubt advance our knowledge of the mechanisms of $G_{\alpha q}$ signaling in immune responses and may help development of therapeutic agents to selectively modulate $\mathrm{G}_{\alpha \mathrm{q}}$ activity to treat immune disorders.

\section{REFERENCES}

Abrahamsen, H., G. Baillie, J. Ngai, T. Vang and K. Nika et al., 2004. TCR- and CD28-mediated recruitment of phosphodiesterase 4 to lipid rafts potentiates TCR signaling. J. Immunol., 173: 4847-4858.

Adams, J.W., Y. Sakata, M.G. Davis, V.P. Sah and Yibin Wang et al., 1998. Enhanced $\mathrm{G}_{\alpha \mathrm{q}}$ signaling: A common pathway mediates cardiac hypertrophy and apoptotic heart failure. Proc. Natl. Acad. Sci. USA., 95: 10140-10145. 
Amatruda, T.T., N.P. Gerard, C. Gerard and M.I. Simon, 1993. Specific interactions of chemoattractant factor receptors with G-proteins. J. Biol. Chem., 268: 10139-10144. PMID: 848668

Amatruda, T.T., S. Dragas-Graonic, R. Holmes and H.D. Perez, 1995. Signal transduction by the formyl peptide receptor. Studies using chimeric receptors and site-directed mutagenesis define a novel domain for interaction with G-proteins. J. Biol. Chem., 270: 28010-28013. PMID: 7499283

Aragay, A.M., A. Katz and M.I. Simon, 1992. The G alpha $\mathrm{q}$ and $\mathrm{G}$ alpha 11 proteins couple the thyrotropin-releasing hormone receptor to phospholipase C in GH3 rat pituitary cells. J. Biol. Chem., 267: 24983-24988. PMID: 1334076

Arai, H. and I.F. Charo, 1996. Differential regulation of G-protein-mediated signaling by chemokine receptors. J. Biol. Chem., 271: 21814-21819. PMID: 8702980

Baeuerle, P. A. and T. Henkel, 1994. Function and activation of NF-kappa B in the immune system. Ann. Rev. Immunol., 12: 141-179. PMID: 8011280

Bakker, R.A., S.B. Schoonus, M.J. Smit, H. Timmerman and R. Leurs et al., 2001. Histamine H(1)-receptor activation of nuclear factor-kappa B: Roles for $G$ beta gamma- and $\mathrm{G}$ alpha(q/11)-subunits in constitutive and agonist-mediated signaling. Mol. Pharmacol., 60: 1133-1142. PMID: 11641442

Ballou, L.M., H.Y. Lin, G. Fan, Y.P. Jiang and R.Z. Lin, 2003. Activated $\mathrm{G}_{\alpha \mathrm{q}}$ inhibits $\mathrm{p} 110 \alpha$ phosphatidylinositol 3-Kinase and Akt. J. Biol. Chem., 278: 23472-23479. DOI: 10.1074/jbc.M212232200

Battey, J. and E. Wada, 1991. Two distinct receptor subtypes for mammalian bombesin-like peptides. Trends Neurosci., 14: 524-528. PMID: 1726343

Bence, K., W. Ma, T. Kozas and X.Y. Huang, 1997. Direct stimulation of Bruton's tyrosine kinase by $\mathrm{G}_{\mathrm{q}}$-protein $\alpha$-subunit. Nature, 389: 296-299. DOI: $10.1038 / 38520$

Borchers, M.T., P.J. Justice, T. Ansay, V. Mancino and M.P. McGarry et al., 2002. Gq signaling is required for allergen-induced pulmonary eosinophilia. J. Immunol., 168: 3543-3549. PMID: 11907117

Brazil, D.P., Z.Z. Yang and Brian A. Hemmings, 2004. Advances in protein kinase B signalling: AKTion on multiple fronts. Trends Biochem. Sci., 29: 233242. DOI: 10.1016/j.tibs.2004.03.006

Brown, A.J., S.M. Goldsworthy, A.A. Barnes, M.M. Eilert and L. Tcheang et al., 2003. The orphan G proteincoupled receptors GPR41 and GPR43 are activated by propionate and other short chain carboxylic acids. J. Biol. Chem., 278: 11312-11319. DOI: 10.1074/jbc.M211609200
Conn, P.J. and J.P. Pin, 1997. Pharmacology and functions of metabotropic glutamate receptors. Annu. Rev. Pharmacol. Toxicol., 37: 205-237. DOI: 10.1146/annurev.pharmtox.37.1.205

Cramer, H., K. Schmenger, K. Heinrich, A. Horstmeyer and H. Boning et al., 2001. Coupling of endothelin receptors to the ERK/MAP kinase pathway. Roles of palmitoylation and G(alpha)q. Eur. J. Biochem., 268: 5449-5459. DOI: 10.1046/j.00142956.2001.02486.x

D'Angelo, D.D., Y. Sakata, J.N. Lorenz, G.P. Boivin and R.A. Walsh et al., 1997. Transgenic Galphaq overexpression induces cardiac contractile failure in mice. Proc. Natl. Acad. Sci. USA., 94: 8121-8126. PMID: 9223325

Dong, C., D.D. Yang, M. Wysk, A.J. Whitmarsh and R.J. Davis et al., 1998. Defective $\mathrm{T}$ cell differentiation in the absence of Jnk1. Science, 282: 2092-2095. PMID: 9851932

Dong, C., R.J. Davis and R.A. Flavell, 2002. MAP kinases in the immune response. Annu. Rev. Immunol., 20: 55-72. PMID: 11861597

Dumitru, C.D., J.D. Ceci, C. Tsatsanis, D. Kontoyiannis and K. Stamatakis et al., 2000. TNF-alpha induction by LPS is regulated posttranscriptionally via a Tpl2/ERK-dependent pathwa. Cell, 103: 10711083. PMID: 11163183

Eguchi, S., H. Iwasaki, H. Ueno, G.D. Frank and E.D. Motley et al., 1999. Intracellular signaling of angiotensin II-induced p70 S6 kinase phosphorylation at Ser(411) in vascular smooth muscle cells. Possible requirement of epidermal growth factor receptor, Ras, extracellular signalregulated kinase and Akt. J. Biol. Chem., 274: 36843-36851. PMID: 10601235

Feighner, S.D., C.P. Tan, K.K. McKee, O.C. Palyha and D.L. Hreniuk et al., 1999. Receptor for motilin identified in the human gastrointestinal system. Science, 284: 2184-2188. DOI: 10.1126/science. 284.5423 .2184

Folli, F., C.R. Kahn, H. Hansen, J.L. Bouchie and E.P. Feener et al., 1997. Angiotensin II inhibits insulin signaling in aortic smooth muscle cells at multiple levels. A potential role for serine phosphorylation in insulin/angiotensin II crosstalk. J. Clin. Invest., 100: 158-2169. DOI: 10.1172/JCI119752

Fredholm, B.B., M.P. Abbracchio, G. Burnstock, G.R. Dubyak and T.K. Harden et al., 1997. Towards a revised nomenclature for P1 and P2 receptors. Trends Pharmacol. Sci., 18: 79-82. 
Fry, D., B. Dayton, S. Brodjiana, C. Ogiela and H. Sidorowicz et al., 2006. Characterization of a neuronal cell line expressing native human Melanin-Concentrating Hormone Receptor 1 (MCHR1). Int. J. Biochem. Cell Biol., 38: 12901299. DOI: 10.1016/j.biocel.2006.01.007

Fukuhara, S., M.J. Marinissen, Mario Chiariello and Jorge Moscat et al., 2000. Signaling from G protein-coupled receptors to ERK5/Big Signaling from $G$ Protein-coupled Receptors to ERK5/Big MAPK 1 Involves $G_{\alpha q}$ and $G \alpha 12 / 13$ Families of Heterotrimeric $G$ Proteins evidence for the existence of a novel Ras and rho-independent pathway. J. Biol. Chem., 275: 21730-21736. DOI: 10.1074/jbc.M002410200

Garcia-Hoz, C., G. Sanchez-Fernandez, M.T. Diaz-Meco, J. Moscat and J. Moscat et al., 2010. $\mathrm{G}_{\alpha \mathrm{q}}$ Acts as an Adaptor Protein in Protein Kinase $\mathrm{C} \zeta$ (PKC $\zeta$ )mediated ERK5 Activation by $\mathrm{G}$ Protein-coupled Receptors (GPCR). J. Biol. Chem., 285: 1348013489. DOI: 10.1074/jbc.M109.098699

Gasparo, M.D., K.J. Catt, T. Inagami, J.W. Wright and T. Unger et al., 2000. International union of pharmacology. XXIII. The angiotensin II receptors. Pharmacol. Rev., 52: 415-472. PMID: 10977869

Goodman, W.G., 2004. Calcium-sensing receptors. Semin. Nephrol., 24: 17-24. DOI: 10.1053/j.semnephrol.2003.08.017

Graness, A., A. Adomeit, R. Heinze, R. Wetzker and C. Liebmann et al., 1998. A novel mitogenic signaling pathway of bradykinin in the human colon carcinoma cell line SW-480 involves sequential activation of $a \mathrm{G}_{\mathrm{q} / 11}$ protein, phosphatidylinositol 3kinase beta and protein kinase Cepsilon. J. Biol. Chem., 273: 32016-32022. PMID: 9822674

Hata, A.N. and R.M. Breyer, 2004. Pharmacology and signaling of prostaglandin receptors: multiple roles in inflammation and immune modulation. Pharmacol. Ther., 103: 147-166. DOI: 10.1016/j.pharmthera.2004.06.003

He, W., F.J.P. Miao, D.C.H. Lin, R.T. Schwandner and Z. Wang et al., 2004. Citric acid cycle intermediates as ligands for orphan G-protein-coupled receptors. Nature, 429: 188-193. DOI: 10.1038/nature02488

Hirasawa, A., K. Tsumaya, T. Awaji, S. Katsuma and T. Adachi et al., 2004. Free fatty acids regulate gut incretin glucagon-like peptide-1 secretion through GPR120. Nat. Med., 11: 90-94. DOI: $10.1038 / \mathrm{nm} 1168$

Imamura, T., K. Ishibashi, S. Dalle, S. Ugi and J.M. Olefsky, 1999. Endothelin-1-induced GLUT4 translocation is mediated via Galpha(q/11) protein and phosphatidylinositol 3-kinase in 3T3-L1 adipocytes. J. Biol. Chem., 274: 33691-33695. PMID: 10559259
Jiang, Z.Y., Q.L. Zhou, A. Chatterjee, E.P. Feener and M.G.J. Myers et al., 1999. Endothelin-1 modulates insulin signaling through phosphatidylinositol 3kinase pathway in vascular smooth muscle cells. Diabetes, 48: 1120-1130. PMID: 10331419

Kane, L.P., J. Lin and A. Weiss, 2000. Signal transduction by the TCR for antigen. Curr. Opin. Immunol., 12: 242-249. PMID: 10781399

Katso, R., K. Okkenhaug, K. Ahmadi, S. White and J. Timms et al., 2001. Cellular function of phosphoinositide 3-kinases: Implications for development, homeostasis and cancer. Annu. Rev. Cell Dev. Biol., 17: 615-675. DOI: 10.1146/annurev.cellbio.17.1.615

Kojima, M., H. Hosoda, Y. Date, M. Nakazato and H. Matsuo et al., 1999. Ghrelin is a growthhormone-releasing acylated peptide from stomach. Nature, 402: 656-660. DOI: 10.1038/45230

Lee, T., R. Schwandner, G. Swaminath, J. Weiszmann and M. Cardozo et al., 2008. Identification and functional characterization of allosteric agonists for the $G$ protein-coupled receptor FFA2. Mol. Pharmacol., 74: 1599-1609. DOI: 10.1124/mol.108.049536

Leeb-Lundberg, L.M., F. Marceau, W. Muller-Esterl, D.J. Pettibone and B.L. Zuraw et al., 2005. International union of pharmacology. XLV. Classification of the kinin receptor family: From molecular mechanisms to pathophysiological consequences. Pharmacol. Rev., 57: 27-77. DOI: 10.1124/pr.57.1.2

Li, W., C.D. Whaley, A. Mondino and D.L. Mueller et al., 1996. Blocked signal transduction to the ERK and JNK protein kinases in anergic CD4+ $\mathrm{T}$ cells. Science, 271: 1272-1276. PMID: 8638107

Liu, L. and N.A. Clipstone, 2007. Prostaglandin F2 $\alpha$ inhibits adipocyte differentiation via a $\mathrm{G}_{\alpha q}$-CalciumCalcineurin-Dependent signaling pathway. J. Cell. Biochem., 100: 161-173. DOI: 10.1002/jcb.21044

Lu, H.T., D.D. Yang, M. Wysk, E. Gatti and I. Mellman et al., 1999. Defective IL-12 production in Mitogen-Activated Protein (MAP) kinase kinase 3 (Mkk3)-deficient mice. EMBO J., 18: 1845-1857. DOI: 10.1093/emboj/18.7.1845

Lynch, K.R., 2002. Lysophospholipid receptor nomenclature. Biochim. Biophys. Acta, 1582: 70-71.

Macdonald, S.G., J.J. Dumas and N.D. Boyd, 1996. Chemical cross-linking of the substance P (NK-1) receptor to the alpha subunits of the $\mathrm{G}$ proteins $\mathrm{Gq}$ and G11. Biochemistry, 35: 2909-2916. DOI: $10.1021 / \mathrm{bi} 952351$ 
Marinissen, M.J., J.M. Servitja and S. Offermanns, 2003. Thrombin protease-activated receptor-1 signals through Gq- and G13-initiated MAPK cascades regulating c-Jun expression to induce cell transformation. J. Biol. Chem., 278: 46814-46825. DOI: $10.1074 /$ jbc.M305709200

McIntosh, K., M.R. Cunningham, L. Cadalbert, J. Lockhart and G. Boyd et al., 2010. Proteinaseactivated receptor-2 mediated inhibition of TNFalpha-stimulated JNK activation-A novel paradigm for G(q/11) linked GPCRs. Cell Signal, 22: 265-273. PMID: 19781631

Merritt, C., H. Enslen, N. Diehl D. Conze and R.J. Davis et al., 2000. Activation of p38 mitogen-activated protein kinase in vivo selectively induces apoptosis of CD8(+) but not CD4(+) T cells. Mol. Cell. Biol., 20: 936-946. PMID: 10629051

Mieda, M. and M. Yanagisawa, 2002. Sleep, feeding and neuropeptides: Roles of orexins and orexin receptors. Curr. Opin Neurobiol., 12: 339-345. PMID: 12049942

Millar, R. P., Z. L. Lu, A.J. Pawson C.A. Flanagan and K. Morgan et al., 2004. Gonadotropin-releasing hormone receptors. Endocr. Rev., 25: 235-275. PMID: 15082521

Misra, R.S., G. Shi, M.E. Moreno-Garcia, A. Thankappan and M. Tighe et al., 2010. G alpha q-containing G proteins regulate $\mathrm{B}$ cell selection and survival and are required to prevent B cell-dependent autoimmunity. J. Exp. Med., 207: 1775-1789. DOI: 10.1084/jem.20092735

Mizuno, N. and H. Itoh, 2009. Functions and regulatory mechanisms of Gq-signaling pathways Neurosignals, 17: 42-54. PMID: 19212139

Narumiya, S., Y. Sugimoto and F. Ushikubi, 1999. Prostanoid receptors: Structures, properties and functions. Physiol. Rev., 79: 1193-1226. PMID: 10508233

Ngai, J., M. Inngjerdingen, T. Berge and K. Tasken et al., 2009. Interplay between the heterotrimeric G-protein subunits Galphaq and Galphai2 sets the threshold for chemotaxis and TCR activation. BMC Immunol., 10: 27-27. PMID: 19426503

Ngai, J., T. Methi, K.W. Andressen, F.O. Levy and K.M. Torgersen et al., 2008. The heterotrimeric Gprotein alpha-subunit Galphaq regulates TCRmediated immune responses through an Lckdependent pathway. Eur. J. Immunol., 38: 32083218. DOI: 10.1002/eji.200838195

Offermanns, S., A. Iida-Klein, G.V. Segre and M.I. Simon, 1996. G alpha q family members couple parathyroid hormone (PTH)/PTH-related peptide and calcitonin receptors to phospholipase $\mathrm{C}$ in COS-7 cells. Mol. Endocrinol., 10: 566-574. PMID: 8732687
Oldham, W. M. and H.E. Hamm, 2008. Heterotrimeric $\mathrm{G}$ protein activation by G-protein-coupled receptors. Nat. Rev. Mol. Cell Biol., 9: 60-71. DOI: 10.1038/nrm 2299

Pages, G., S. Guerin, D. Grall, F. Bonino and A. Smith et al., 1999. Defective thymocyte maturation in $\mathrm{p} 44$ MAP kinase (Erk 1) knockout mice. Science, 286: 1374-1377. PMID: 10558995

Pang, I. H. and P. C. Sternweis 1989. Isolation of the alpha subunits of GTP-binding regulatory proteins by affinity chromatography with immobilized beta gamma subunits. Proc. Natl. Acad. Sci. USA., 86: 7814-7818. PMID: 2510152

Pang, I.H. and P.C. Sternweis 1990. Purification of unique alpha subunits of GTP-binding regulatory proteins ( $\mathrm{G}$ proteins) by affinity chromatography with immobilized beta gamma subunits. J. Biol. Chem., 265: 18707-18712. PMID: 2120237

Parmentier, C.N., E. Fuerst, J. McDonald, H. Bowen and T.H. Lee et al., 2012. Human T(H)2 cells respond to cysteinyl leukotrienes through selective expression of cysteinyl leukotriene receptor 1 . J. Allergy Clin. Immunol., 129: 1136-1142. PMID: 22391114

Pennefather, J.N., A. Lecci, M.L. Candenas, E. Patak and F.M. Pinto et al., 2004. Tachykinins and tachykinin receptors: A growing family. Life Sci., 74: 1445-1463. PMID: 14729395

Poyner, D.R., P.M. Sexton, I. Marshall, D.M. Smith and R. Quirion et al., 2002. International Union of Pharmacology. XXXII. The mammalian calcitonin gene-related peptides, adrenomedullin, amylin and calcitonin receptors. Pharmacol. Rev., 54: 233-246. PMID: 12037140

Prescott, S.M., G.A. Zimmerman, D.M. Stafforini and T.M. McIntyre et al., 2000. Platelet-activating factor and related lipid mediators. Annu. Rev. Biochem., 69: 419-445. DOI: 10.1146/annurev.biochem.69.1.419

Qian, A., W. Wang and B.M. Sanborn, 1998. Evidence for the involvement of several intracellular domains in the coupling of oxytocin receptor to $G$ alpha(q/11). Cell Signal, 10: 101-105. PMID: 9481484

Qiu, J., M. A. Bosch, S.C. Tobias, D.K. Grandy and T.S. Scanlan et al., 2003. Rapid signaling of estrogen in hypothalamic neurons involves a novel G-proteincoupled estrogen receptor that activates protein kinase C. J. Neurosci., 23: 9529-9540. PMID: 14573532 
Rhee, S.G., 2001. Regulation of phosphoinositidespecific phospholipase C. Annu. Rev. Biochem., 70: 281-312. PMID: 11395409

Rincon, M., A. Whitmarsh, D.D. Yang, L. Weiss and B. Derijard et al., 1998a. The JNK pathway regulates the In vivo deletion of immature CD4(+)CD8(+) thymocytes. J. Exp. Med., 188: 1817-1830. PMID: 9815259

Rincon, M., H. Enslen, J. Raingeaud, M. Recht and T. Zapton et al., 1998b. Interferon-gamma expression by Th1 effector $\mathrm{T}$ cells mediated by the p38 MAP kinase signaling pathway. EMBO, J., 17: $2817-$ 2829. DOI: $10.1093 / \mathrm{emboj} / 17.10 .2817$

Roux, N.D., E. Genin, J.C. Care, F. Matsuda and J.L. Chaussain, 2003. Hypogonadotropic hypogonadism due to loss of function of the KiSS1-derived peptide receptor GPR54. Proc. Natl. Acad Sci. USA., 100: 10972-10976. DOI: 10.1073/pnas. 1834399100

Russell, F.D., 2004. Emerging roles of urotensin-II in cardiovascular disease. Pharmacol. Ther., 103: 223243. PMID: 5464591

Sabapathy, K. and T. Kallunki, 2001. c-Jun NH2terminal kinase (JNK)1 and JNK2 have similar and stage-dependent roles in regulating $\mathrm{T}$ cell apoptosis and proliferation. J. Exp. Med., 193: 317-328. PMID: 11157052

Sabapathy, K., Y. Hu, T. Kallunk, M. Schreiber and D. Jean-Pierre et al., 1999. JNK2 is required for efficient T-cell activation and apoptosis but not for normal lymphocyte development. Curr. Biol., 9: 116-125. PMID: 10021384

Saward, L. and P. Zahradka, 1997. Angiotensin II activates phosphatidylinositol 3-kinase in vascular smooth muscle cells. Circ. Res., 81: 249-257. PMID: 9242186

Seminara, S. B., S. Messager, E.E. Chatzidaki, B. Sc and R. Rosemary et al., 2003. The GPR54 gene as a regulator of puberty. N. Engl. J. Med., 349: 16141627. DOI: 10.1056/NEJMoa035322

Shahrestanifar, M., X. Fan and D.R. Manning, 1999. Lysophosphatidic acid activates NF-kappaB in fibroblasts. A requirement for multiple inputs. J. Biol. Chem., 274: 3828-3833. PMID: 9920937

Shapira, H., I. Amit, M. Revach Y. Oron and J.F. Battey et al., 1998. Galpha14 and Galphaq mediate the response to trypsin in Xenopus oocytes. J. Biol. Chem., 273: 19431-19436. PMID: 9677362

Shapira, H., J. Way, D. Lipinsky, Y. Oron and J.F. Battey et al., 1994. Neuromedin B receptor, expressed in Xenopus laevis oocytes, selectively couples to $G$ alpha $\mathrm{q}$ and not $\mathrm{G}$ alpha 11. FEBS Lett., 348: 89-92. PMID: 8026589
Shi, G., S. Partida-Sanchez, R.S. Misra, M. Tighe and M.T. Borchers et al., 2007. Identification of an alternative $\mathrm{G}$ \{alpha\}q-dependent chemokine receptor signal transduction pathway in dendritic cells and granulocytes. J. Exp. Med., 204: 27052718. PMID: 17938235

Shulkes, A. and G.S. Baldwin, 1997. Biology of gut cholecystokinin and gastrin receptors. Clin. Exp. Pharmacol. Physiol., 24: 209-216. PMID: 9131287

Soga, T., S. Matsumoto, T. Oda, T. Saito and H. Hiyama et al., 2002. Molecular cloning and characterization of prokineticin receptors. Biochim. Biophys. Acta, 1579: 173-179. PMID: 12427552

Strathmann, M.P. and M.I. Simon, 1991. G alpha 12 and $G$ alpha 13 subunits define a fourth class of $G$ protein alpha subunits. Proc. Natl. Acad. Sci. USA., 88: 5582-5586. PMID: 1905812

Sun, B., K. Fujiwara, S. Adachi and K. Inoue, 2005. Physiological roles of prolactin-releasing peptide. Regul. Pept., 126: 27-33. PMID: 15620410

Takahashi, T., T. Taniguchi, H. Konishi, U. Kikkawa and Y. Ishikawa et al., 1999. Activation of Akt/protein kinase $\mathrm{B}$ after stimulation with angiotensin II in vascular smooth muscle cells. Am. J. Physiol., 276: H1927-H1934. PMID: 10362672

Tang, X., I.H. Batty and C.P. Downes, 2002. Muscarinic receptors mediate phospholipase C-dependent activation of protein kinase $\mathrm{B}$ via $\mathrm{Ca} 2+, \mathrm{ErbB} 3$ and phosphoinositide 3-kinase in $1321 \mathrm{~N} 1$ astrocytoma cells. J. Biol. Chem., 277: 338-344. DOI: 10.1074/jbc.M108927200

Tanis, J.E., J.J. Moresco, R.A. Lindquist and M.R. Koelle, 2008. Regulation of serotonin biosynthesis by the $\mathrm{G}$ proteins Galphao and Galphaq controls serotonin signaling in Caenorhabditis elegans. Genetics, 178: 157-169. PMID: 18202365

Vaidyula, V.R. and A.K. Rao, 2003. Role of Galphaq and phospholipase C-beta2 in human platelets activation by thrombin receptors PAR1 and PAR4: Studies in human platelets deficient in Galphaq and phospholipase C-beta2. Br. J. Haematol., 121: 491496. PMID: 12716374

Vassart, G. and L. Pardol., 2004. A molecular dissection of the glycoprotein hormone receptors. Trends Biochem. Sci., 29: 119-126.

Vicente-Manzanares, M. and F. Sanchez-Madrid, 2004. Role of the cytoskeleton during leukocyte responses. Nat. Rev. Immunol., 4: 110-122. DOI: 10.1038/nri1268

Wang, Y., Y. Li, Y. He, Y. Sun and W. Sun et al., 2011. Expression of $G$ protein $\alpha q$ subunit is decreased in lymphocytes from patients with rheumatoid arthritis and is correlated with disease activity. Scand J. Immunol., 75: 203-209. DOI: 10.1111/j.13653083.2011.02635.x 
Weichhart, T. and M.D. Saemann, 2008. The The $\mathrm{PI} 3 \mathrm{~K} / \mathrm{Akt} / \mathrm{mTOR}$ pathway in innate immune cells: Emerging therapeutic applications. Ann. Rheum Dis., 67: iii70-iii74. DOI: 10.1136/ard.2008.098459

Wellendorph, P., K.B. Hansen, A. Balsgaard and J.R. Greenwood et al., 2005. Deorphanization of GPRC6A: A promiscuous $1-\alpha$-amino acid receptor with preference for basic amino acids. Mol. Pharmacol., 67: 589-597. DOI: 10.1124/mol.104.007559

Wess, J., 2004. Muscarinic acetylcholine receptor knockout mice: Novel phenotypes and clinical implications. Annu. Rev. Pharmacol. Toxicol., 44: 423-450.

DOI:

10.1146/annurev.pharmtox.44.101802.121622

Wettschureck, N. and S. Offermanns, 2005. Mammalian $\mathrm{G}$ proteins and their cell type specific functions. Physiol. Rev., 85: 1159-1204. DOI: 10.1152/physrev.00003.2005

White, C. D., M. Coetsee, K. Morgan, C.A. Flanagan and R.P. Millar et al., 2008. A crucial role for Galphaq/11, but not Galphai/o or Galphas, in gonadotropin-releasing hormone receptor-mediated cell growth inhibition. Mol. Endocrinol., 22: 25202530. DOI: $10.1210 /$ me.2008-0122

Wittmann, S., D. Frohlich and S. Daniels, 2002. Characterization of the human fMLP receptor in neutrophils and in Xenopus oocytes. Br. J. Pharmacol., 135: 1375-1382. DOI: 10.1038/sj.bjp.0704592
Wu, D., A. Katz and M.I. Simon, 1992. Activation of phospholipase $\mathrm{C}$ by alpha 1 -adrenergic receptors is mediated by the alpha subunits of Gq family. J. Biol. Chem., 267: 25798-25802. PMID: 1334487

Xie, P., D.D. Browning, N. Hay, N. Mackman and R.D. Ye et al., 2000. Activation of NF-kappa B by bradykinin through a Galpha(q)- and Gbeta gammadependent pathway that involves phosphoinositide 3-kinase and Akt. J. Biol. Chem., 275: 2490724914. DOI: $10.1074 /$ jbc.M001051200

Yamashita, M., M. Kimura, M. Kubo, C. Shimizu and T. Tada et al., 1999. T cell antigen receptormediated activation of the Ras/mitogen-activated protein kinase pathway controls interleukin 4 receptor function and type-2 helper $\mathrm{T}$ cell differentiation. Proc. Natl. Acad. Sci. USA., 96: 1024-1029. PMID: 9927687

Yang, D.D., D. Conze, A.J. Whitmarsh, T. Barrett and R.J. Davis et al., 1998. Differentiation of CD4+ T cells to Th1 cells requires MAP kinase JNK2. Immunity, 9: 575-585. PMID: 9806643 